\title{
GENETIC VARIABILITY IN NATURAL POPULATIONS OF Zeyheria montana Mart. FROM THE BRAZILIAN CERRADO
}

\author{
Bianca Waléria Bertoni1; Spartaco Astolfi Filho²; Ernani Ronie Martins 3 ; Carlos Ferreira \\ Damião Filho4; Suzelei de Castro França ${ }^{1}$; Ana Maria Soares Pereira ${ }^{1 *}$; Mariana Pires de \\ Campos Telles; ${ }^{5}$ José Alexandre F. Diniz Filho ${ }^{6}$ \\ ${ }^{1}$ UNAERP - Unidade de Biotecnologia de Plantas Medicinais, Av. Costábile Romano, 2201 - 14096-380 - \\ Ribeirão Preto, SP - Brasil. \\ ${ }^{2} U F A M$ - Centro de Apoio Multidisciplinar, Av. General Rodrigo Otávio Ramos, 3000 - 69077-000 - Manaus, \\ AM - Brasil. \\ ${ }^{3}$ UFMG - Núcleo de Ciências Agrárias, C.P. 135 - 39404-006 - Montes Claros, MG - Brasil. \\ ${ }^{4}$ UNESP/FCAV - Depto. de Biologia Aplicada à Agropecuária, Via de Acesso Prof. Paulo Donato Castellano, s/n - \\ 14870-000 - Jaboticabal, SP - Brasil. \\ ${ }^{5}$ UCG - Lab. de Genética \& Biodiversidade, Av. Universitária, 1440 - 74605-010 - Goiânia, GO - Brasil. \\ ${ }^{6}$ UFG/ICB - Depto. de Biologia Geral - C.P. 131 - 74001-970 - Goiânia, GO - Brasil. \\ *Corresponding author <apereira@unaerp.br>
}

\begin{abstract}
Zeyheria montana, an endemic species of the Bignoniaceae family from the Brazilian Cerrado's known for its anti-cancer properties, is widely used as imuno stimulant in the popular medicine and its therapeutic activity must be validated by scientific data. The objective of this work was to evaluate the genetic variability of eight plant populations collected within the state of São Paulo, Brazil, via Random Amplification of Polymorphic DNA (RAPD) used as molecular markers. After an optimized protocol for the amplification reaction, nine selected primers generated 105 reproducible bands, indicating up to $60 \%$ polymorphism. Analysis of molecular variance (AMOVA) revealed higher genetic variation within populations (84.03\%) than among populations (15.97\%). The variation values estimated by $\phi_{\mathrm{ST}}(0.160)$ indicated moderate to high inter population structuration. Levels of similarity inter plants with genetic and geographical distances, estimated by the unweighted pair-group method analysis (UPGMA) clustering and non-metric multidimensional scaling (NMDS) ordination methods and by the Mantel test $(-0.2345 \mathrm{p}=0.118)$ denoted that the structure found follows the island model, which assumes that a single population of infinite size may have initiated the existing populations of Zeyheria montana, with no spatial position correlation. Based on the obtained data, a germplasm bank from individuals representing the species variability was established. Furthermore the information here reported can be of importance to develop strategies for the conservation of $Z$. montana. Key words: Bignoniaceae, germplasm bank, bolsa-de-pastor, conservation
\end{abstract}

\section{VARIABILIDADE GENÉTICAENTRE E DENTRO DE POPULAÇÕES NATURAIS DE Zeyheria montana Mart. DO CERRADO BRASILEIRO}

RESUMO: Zeyheria montana, planta arbustiva da família Bignoniaceae, é uma espécie endêmica do Cerrado e possui atividade anti-câncer, sendo utilizada como estimulante na medicina popular. O objetivo deste estudo foi avaliar a variabilidade genética de oito populações localizadas no estado de São Paulo, utilizando marcadores moleculares de Polimorfismo de DNA Amplificado ao Acaso (RAPD). Após a otimização da reação de amplificação, nove iniciadores selecionados geraram 105 fragmentos RAPD reprodutíveis, sendo que a maioria $(60,0 \%)$ foi polimórfica. A análise molecular de variância (AMOVA) mostrou que a variabilidade dentro de populações $(84,03 \%)$ foi maior que entre populações $(15,97 \%)$. As estimativas de variação $\phi_{\mathrm{ST}}(0,1597)$ indicam estruturação populacional moderadamente alta. O agrupamento por meio de UPGMA, a ordenação pelo NMDS e o teste de Mantel entre as matrizes de distâncias genéticas e geográficas demonstraram que a estruturação encontrada segue um modelo de "ilhas", onde uma única população de tamanho infinito pode ter dado origem às populações atuais de Zeyheria, sem relação com sua posição espacial. Com base nos resultados obtidos foi estruturado um banco de germoplasma de indivíduos, representando a variabilidade da espécie. Adicionalmente, as informações deste estudo são importantes para dar suporte a estratégias de conservação de $Z$. montana.

Palavras-chave: Bignoniaceae, banco de germoplasma, bolsa-de-pastor, conservação 


\section{INTRODUCTION}

Along the last decades, some areas within biomes like the Atlantic Forest and Cerrado, have been intensely exploited for cultivation, disintegrating the native vegetation of biomes in small and isolated fragments (Myers et al., 2000; Klink \& Machado, 2005). Consequently, the conservation of endemic plants under high anthropic pressure, mainly those plants from the Cerrado, represents a great world challenge (Felfili et al., 2004; Giulietti et al., 2005; Brandon et al., 2005).

The molecular markers technology is an important tool for biodiversity conservation programs of plants under risk of extinction, since it allows the estimation of the genetic variability among and within populations and, consequently, provides information on the genetic structure of those natural populations. The Random Amplification of Polymorphic DNA (RAPD) (Williams et al., 1990; Welsh \& McClelland, 1990) facilitates the identification and the differentiation of genotypes, for a first screening of genetic variability, and allows correlating it to phenotypic expressions and determining possible phylogenetic relationships among different species germplasms or populations (Ferreira \& Grattapaglia, 1998; Daher et al., 2002; Kroth et al., 2005; Sandhu et al., 2006). Through the RAPD technique it is possible to identify atypical genotypes that can be introduced into germplasm banks, permitting its multiplication in large scale when required (Lacerda et al., 2002).

Zeyheria montana Mart. a shrub, widespread throughout the Brazilian Cerrados, has been exposed to genetic erosion. Z. montana seeds are wind dispersed and according to Bittencourt Jr. \& Semir (2004) its flower pollination is carried out mainly by the Colibri serrirostris. Well known in Brazil as bolsa de pastor (shepherd bag), this species is extensively used for the treatment of skin pathologies (Corrêia, 1931). Jácome et al. (1999) reported the presence of lapachol and naphthoquinones in Zeyheria root extracts. The efficacy of lapachol as anti-inflammatory agent (Almeida et al., 1990), gastric anti-ulcer (Goel et al., 1987) and anti-neoplasic of low toxicity (Santana et al., 1980) has been reported.

Structure and genetic variability of eight populations of Z. montana, collected in Cerrados of the São Paulo state, were RAPD-investigated and atypical genotypes introduced into a germplasm bank to assure multiplication in large scale when required.

\section{MATERIAL AND METHODS}

\section{Areas of collection}

Z. montana individuals (167) were grouped in eight populations according to their geographical occurrence, due to the small number of individuals per locality. The populations were codified by capital letters, every letter corresponding to one or more localities, as follows: A (27 individuals): Sales Oliveira, Morro Agudo, Orlândia, São Joaquim da Barra and Jaborandi; B (10 individuals): São Carlos and Itirapina; C (13 individuals): Assis and Paraguaçu Paulista; D (32 individuals): Penápolis and Avanhandava; E (16 individuals): Nipoã, Américo de Campo and Duplo Céu; F (12 individuals): Reserva Biológica de Mogi-Guaçu; G (04 individuals): Pratânia; H (53 individuals): Franca, Pedregulho, Rifaina, Cristais Paulista and Parque Estadual das Furnas de Bom Jesus (Figure 1).

The collection of localities was selected to represent the distribution area of the species within the state of São Paulo. Plants were randomly sampled observing the precision area of $10 \mathrm{~m}$, and the geographical location was determined with Global Positioning System (GPS) and the distance among populations (Table 1) was estimated using the GPS TRACKMAKER 11.7 software (Ferreira Jr., 2001).

Table 1 - Z. montana populations: geographical localization, number of accessions and distance inter populations. Data recorded by GPS TRACKMAKER 11.4.

\begin{tabular}{|c|c|c|c|c|c|c|c|c|c|c|c|c|}
\hline \multirow{2}{*}{ Population } & \multirow{2}{*}{ Longitude } & \multirow{2}{*}{ Latitude } & \multirow{2}{*}{ Altitude } & \multirow{2}{*}{$\begin{array}{c}\mathrm{N}^{\circ} \text { of } \\
\text { accessions }\end{array}$} & \multicolumn{8}{|c|}{ Distance inter populations } \\
\hline & & & & & A & $\mathrm{B}$ & $\mathrm{C}$ & $\mathrm{D}$ & $\mathrm{E}$ & $\mathrm{F}$ & G & $\mathrm{H}$ \\
\hline & & & $\mathrm{m}$ & & -- & -1 & -- & ---- & $\mathrm{km} \mathrm{-.-.}$ & - & 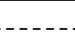 & - n \\
\hline A & $-48^{\circ} 16^{\prime}$ & $-20^{\circ} 41^{\prime}$ & 731 & 27 & 0 & 156 & 334 & 227 & 190 & 193 & 246 & 68.69 \\
\hline B & $-47^{\circ} 47^{\prime}$ & $-22^{\circ} 15^{\prime}$ & 801 & 10 & & 0 & 270 & 230 & 256 & 76.52 & 113 & 213 \\
\hline $\mathrm{C}$ & $-50^{\circ} 34^{\prime}$ & $-22^{\circ} 22^{\prime}$ & 505.1 & 13 & & & 0 & 134 & 219 & 343 & 186 & 4.02 \\
\hline $\mathrm{D}$ & $-49^{\circ} 57^{\prime}$ & $-21^{\circ} 23^{\prime}$ & 405.1 & 32 & & & & 0 & 96.54 & 307 & 204 & 294 \\
\hline $\mathrm{E}$ & $-49^{\circ} 42^{\prime}$ & $-20^{\circ} 21^{\prime}$ & 451.1 & 16 & & & & & 0 & 322 & 267 & 243 \\
\hline $\mathrm{F}$ & $-47^{\circ} 09$ & $-22^{\circ} 15^{\prime}$ & 626.7 & 12 & & & & & & 0 & 165 & 228 \\
\hline G & $-48^{\circ} 41^{\prime}$ & $-22^{\circ} 49^{\prime}$ & 635.5 & 4 & & & & & & & 0 & 312 \\
\hline \multirow[t]{2}{*}{$\mathrm{H}$} & $-47^{\circ} 27^{\prime}$ & $-20^{\circ} 22^{\prime}$ & 976.1 & 53 & & & & & & & & 0 \\
\hline & & & Total & 167 & & & & & & & & \\
\hline
\end{tabular}




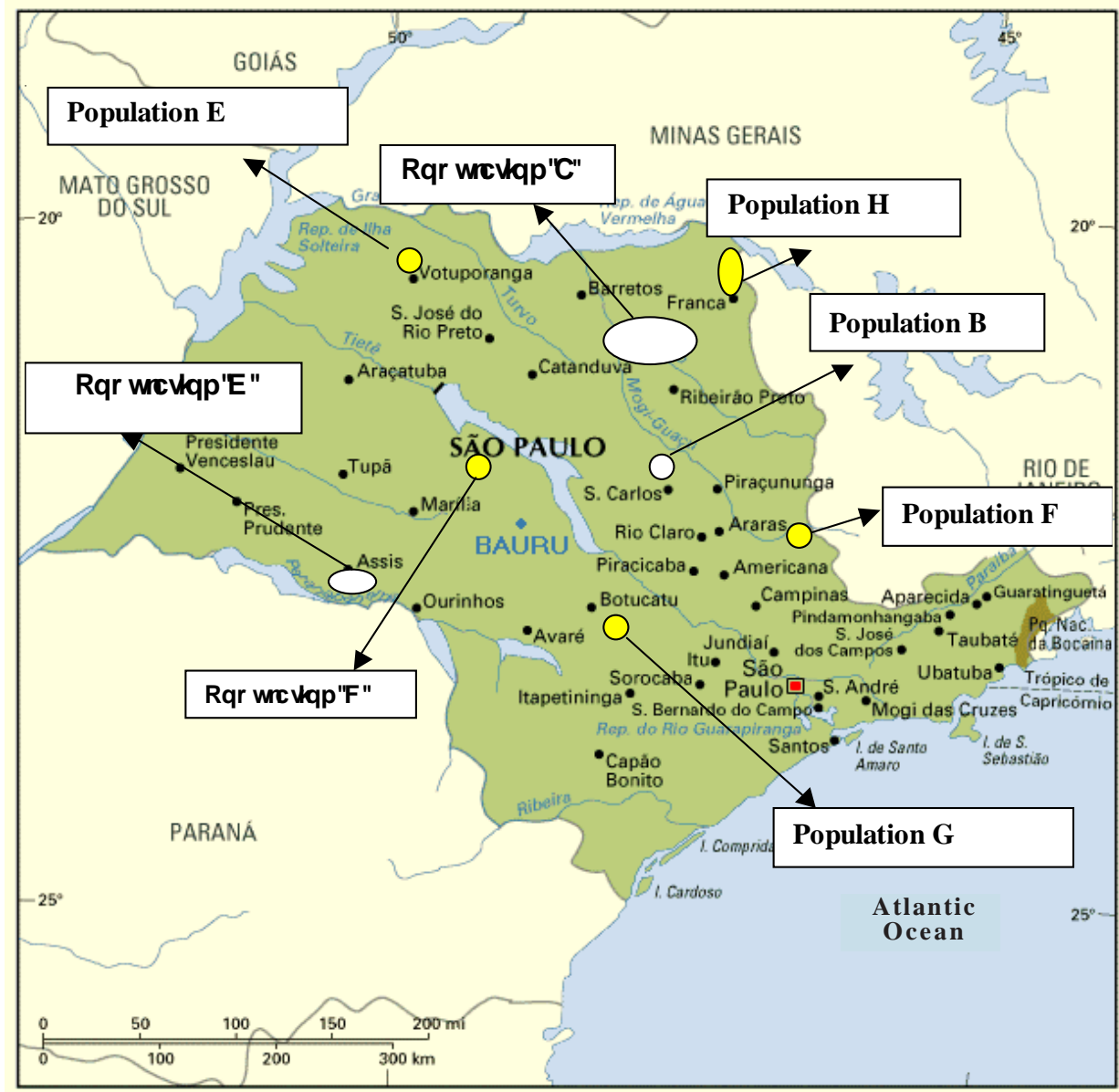

Figure 1 - Geographical localization of Z. montana populations within the state of São Paulo. Yellow and white circles show UPGMA clustering obtained by hierarchical arrangement dendogram.

\section{RAPD protocol optimization}

The genomic DNA of young leaves was extracted following methodology established by Doyle \& Doyle (1987). Samples of Z. montana DNA were primarily assayed with 110 arbitrary primers, each one with ten bases on average (Operon Life Technology e Biosynthesis Incorporated), following amplification protocol described by Ferreira \& Grattapaglia (1998) and 35 of them were initially selected.

Reaction products were separated by electrophoresis in a $1.5 \%$ (w.v.) agarose gel and visualized by ethidium bromide staining. DNA molecular weight markers (100 pb and $1000 \mathrm{pb})$ were added to each fingerprint gel performed with material from 48 individuals. The gels stained with ethidium bromide were photographed under UV light (Image Master VDS, Pharmacia Biotech apparatus). Only intense and reproducible bands were considered. Control samples containing all reaction products except DNA, were examined to guarantee the nonexistence of auto-amplification and contaminants.

\section{Genetic variability within and among populations}

Binary data matrix (i.e., presence or absence of bands) obtained from the RAPD gel readings were used to calculate a descriptive analysis of genetic variability based on proportion of polymorphic loci, using TFPGA 1.3 (Tools For Population Genetic Analyses) (Miller, 1997). The proportion of genetic variation among populations was then estimated by the $\Phi_{\text {ST }}$ statistics, measuring the among-population component of genetic divergence. Its statistical significance was established by 5000 random permutations using ARLEQUIN (version 2000, Schneider et al., 2000).

To estimate the genetic divergence inter populations, a dendrogram representing the hierarchical arrangement of classified populations was constructed, using the unweighted pair-group method analysis (UPGMA) clustering technique of pairwise genetic distance. Cophenetic correlation was used to evaluate if clustering is generating an acceptable representation of genetic distances, and values higher than 0.8 are usually considered as a cut-off. Since population-level genetic divergence processes generate non-hierarchical 
patterns of genetic divergence (Rodrigues \& DinizFilho, 1998), a non-metric multidimensional scaling (NMDS) was used to generate a continuous space, with two or three dimensions, in which populations are projected. The "badness-of-fit" was measured by the stress-value, for which values equal to zero indicate perfect fit between genetic distances and their representation in the reduced NMDS space.

Spatial patterns in genetic distances were investigated using Mantel test of matrix correspondence (Manly, 1986). The standardized Mantel statistics is actually the Pearson correlation between genetic and geographic distances, but tested under a randomization protocol. Multivariate analyses were performed in NTSYS 1.5 (Numerical Taxonomy and Multivariate Analysis System) (Rohlf, 1989).

\section{RESULTS AND DISCUSSION}

\section{Optimization of the RAPD amplification protocol and polymorphism}

From the 35 primers chosen initially, nine were selected (Table 2) due to polymorphism and high band intensity. After optimization of the Polymerase Chain Reaction (PCR) for the Z. montana genetic material, the following RAPD protocol was established (final volume of the amplification reaction $=30 \mu \mathrm{L}$ ): $3.0 \mu \mathrm{L}$ buffer Tp 10X; $3.0 \mu \mathrm{L}$ dNTPs $(2.5 \mathrm{mM}) ; 1.8 \mu \mathrm{L}$ $\mathrm{MgCl}_{2}(25 \mathrm{mM}) ; 4.0 \mu \mathrm{L}$ primer $\left(10 \mathrm{ng} \mu \mathrm{L}^{-1}\right) ; 0.4 \mu \mathrm{L}$ Taq DNA polymerase enzyme (5 $\left.\mathrm{U}^{-1}\right)$ and $4.0 \mu \mathrm{L}$ DNA sample (5 ng $\mu \mathrm{L}^{-1}$ ). The amplification was carried out on a thermocycler according to the following procedure: two cycles with an initial denaturation of DNA for $2 \mathrm{~min}$ at $94^{\circ} \mathrm{C}, 1 \mathrm{~min}$ annealing at $37^{\circ} \mathrm{C}, 2$ min extension at $72^{\circ} \mathrm{C}$, folllowed by 33 cycles with a initial denaturation of DNA for $10 \mathrm{sec}$ at $94^{\circ} \mathrm{C}, 20 \mathrm{sec}$ annealing at $40^{\circ} \mathrm{C}, 2$ min extension at $72^{\circ} \mathrm{C}$.

The nine selected primers generated 105 bands for the eight populations, out of which 65 bands were polymorphic and 40 were monomorphic. The number of bands per primer ranged from 8-18 (Table 2). A typical example of polymorphism detected with the primer OPM-02 is shown in Figure 2.

\section{Genetic variability within and among populations}

The descriptive statistics for RAPD markers

Table 2 - Number of polymorphic and monomorphic bands of RAPD molecular markers obtained for 167 individuals of $Z$. montana representing eight populations.

\begin{tabular}{llrcc}
\hline \multirow{2}{*}{ Primers } & \multicolumn{1}{c}{ Sequence $\left(5^{\prime} \rightarrow 3^{\prime}\right)$} & Number of bands \\
\cline { 3 - 5 } & & 18 & Polymorphic & Monomorphic \\
\hline 2G4-62 & GAG TTC GTG ATC CTT GAT CTG & 8 & 16 & 2 \\
1 H9-35 & AGC GAC CAG GTT TAT TTC ACT & 8 & 4 & 4 \\
1 H9-43 & ATC ACC GTA CTC TCC TGC & 13 & 10 & 6 \\
OPB-04 & ATG TTG ATT GGT TGT CTG G & 10 & 4 & 3 \\
OPQ-20 & GGA CTG GAG T & 9 & 4 & 5 \\
OPAV-15 & TCG CCC AGT G & 12 & 9 & 3 \\
OPM-02 & GGC AGC AGG T & 18 & 10 & 8 \\
OPA-02 & TGC ACG CCT C & 9 & 6 & 3 \\
\hline & Total & 105 & 65 & 40 \\
\hline
\end{tabular}

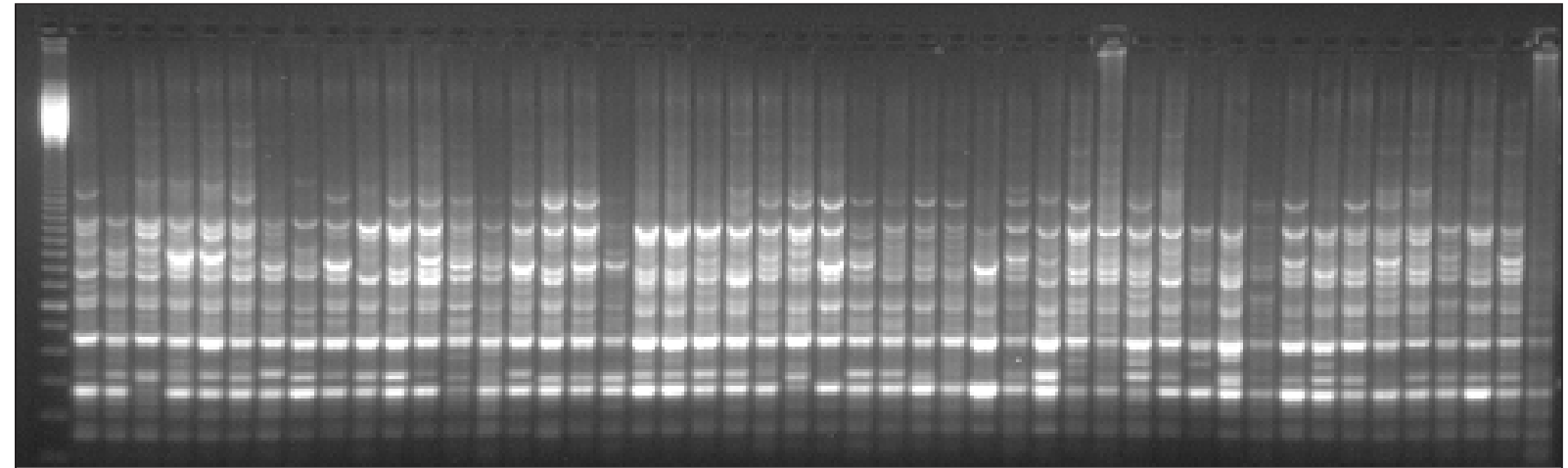

Figure 2 - Gel electrophoresis on agarose of RAPD-PCR products of natural populations of Zeyheria montana. Wells 2 to 49 contain the DNA products of eight populations synthesized using the primer OPM-2. Molecular markers $100 \mathrm{pb}$. 
of Z. montana, of the eight investigated populations, for the 105 investigated loci is in Table 3. Among the 167 individuals there was $60 \%$ of polymorphic loci. The highest percentage of polymorphic loci $(44.00 \%)$ was recorded in population $\mathbf{H}$, followed by the populations C (41.90\%), D and E (40.95\%), and A and B (37.14\%). The analysis of molecular variance based on RAPD markers showed that $84.03 \%$ of the genetic diversity is in the intra-population component. The genetic variability among populations was significant with $\Phi_{\text {ST }}$ estimates of $0.1597(P<0.001)$.

Genetic divergence among $Z$. montana populations resulted in a branching pattern (Figure 3), defined by UPGMA clustering based on the genetic distances determined by pairwise $\Phi_{\mathrm{ST}}$. The dendrogram displays two clusters, the first one corresponding to populations $\mathbf{A}, \mathbf{B}$ and $\mathbf{C}$, and the second to populations $\mathbf{D}, \mathbf{E}, \mathbf{F}, \mathbf{G}$ and $\mathbf{H}$, with a very high similarity

Table 3 - Basic descriptive statistics for RAPD markers of Z. montana populations found within the state of São Paulo, size of sampling and percentage of polymorphic loci (P).

\begin{tabular}{lcc}
\hline Populations & $\mathrm{n}$ & $\mathrm{P}$ \\
\hline A & 27 & 37.14 \\
B & 10 & 37.14 \\
C & 13 & 41.90 \\
D & 32 & 40.95 \\
E & 16 & 40.95 \\
F & 12 & 34.29 \\
G & 4 & 20.00 \\
H & 53 & 44.76 \\
\hline Total & 167 & 60.00 \\
\hline
\end{tabular}

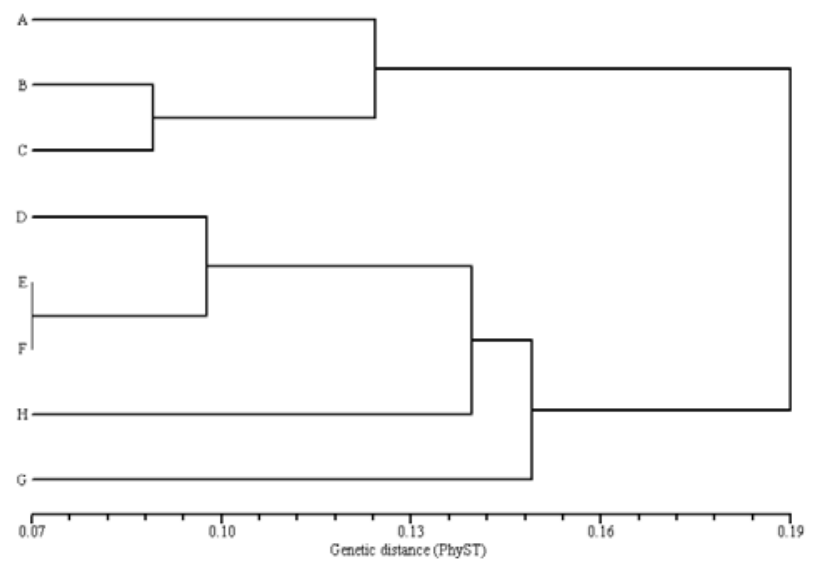

Figure 3 - Genetic divergence pattern among 8 Z. Montana population (A-H represent the populations), defined by UPGMA clustering, based on the genetic distances determined by $\Phi_{\text {ST }}$ pair-by-pair.The Cophenetic correlation was equal to 0.6755 . between populations $\mathbf{E}$ and $\mathbf{F}$. However, since the cophenetic correlation was low (0.675), this clustering pattern can be difficult to be interpreted in terms of genetic population differentiation. In the 3-D solution of the NMDS, the stress-value was relatively low (0.137), indicating a reasonable good representation of the pairwise $\Phi_{\text {ST }}$, but the 3-D plot shows an equidistant pattern of genetic divergence among local populations (Figure 4). Thus, both UPGMA and NMDS suggest that there are no clear geographic patterns of genetic divergence and that each population occupies an unique position in the genetic hyperspace. These results of multivariate exploratory analysis using UPGMA and NMDS are confirmed by the Mantel test. No spatial pattern was observed, since there was no significant correlation among genetic and geographic distances $(r=-0.21277 ; P=0.117$ with 5000 permutations).

According to Parker et al. (1998), careful control of the amplification conditions evaluated during the optimization of the polimerase chain reaction (PCR) is very important, because the RAPD protocol may produce some artifactual amplification products that compromise the reproducibility of band patterns and confound data interpretation. Moreover, optimized PCR, as performed here to obtain molecular data, facilitates new approaches with the same species or with species from the same taxonomic family, Bignoniaceae, also considered endemic species from the Cerrado with phytochemical and pharmacological potential.

The high variability detected among $Z$. montana natural populations attests the effectiveness of the RAPD molecular markers to detect genetic variability, confirmed by the number of polymorphic bands (Table 2) and by the analysis of molecular variance. Several examples of successful works using RAPD to analyze the variability and genetic structure of natural populations of plants are cited in the literature: Russell et al. (1993 - cocoa); Song et al. (1999 - rice); Gillies et al. (1999 - mahogany); Wadt \& Kageyama (2004 Piper); Gauer \& Cavalli-Molina (2000 - Ilex);

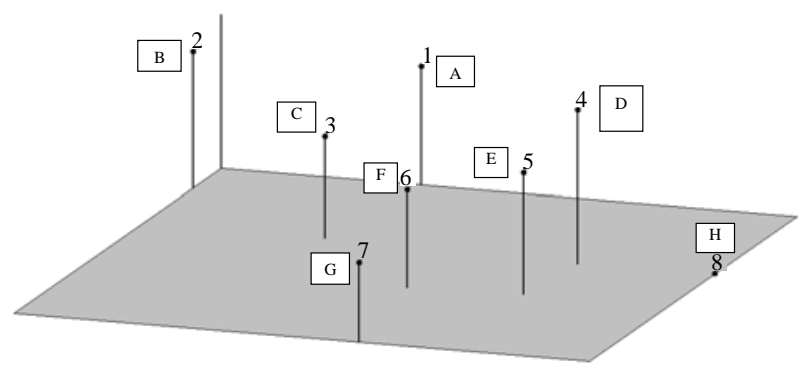

Figure 4 - Divergence pattern among the 8 populations of $Z$. montana, according to NMDS 3-D ordination (Final Stress $=0.1368)$. 
Arnholdt-Schmitt (2000 - Hypericum); Sales et al. (2001 - Digitalis); Ciampi et al. (2003 - Tabebuia). Soares et al. (2007 - Dipteryx).

A significant genetic population structuration was observed in Zeyheria montana, estimated by $\boldsymbol{\Phi}_{\text {ST }}$ (0.159), which, according to Wrigth (1978), indicates a moderately high population structuration. Available data concerning genetic diversity are very important because they may guide new conservation approaches. Accessions of threatened species that present high population structuration like Z. montana, that are being maintained in germplasm banks, should in the future be reintroduced into the same locality from where they were collected, because these individuals have already incorporated vital local adaptations that would disappear in case of mixing populations (Haig, 1998). A different pattern of population structuration was found for RAPD data of Tabebuia impetinosa, another Bignoniaceae, a tree species found in anthropic fragments. Using AMOVA, a slightly lower variability among populations (about 6.5\%) was found (Ciampi et al., 2003).

The dispersion of seeds of both Zeyheria montana and Tabebuia impetinosa is accomplished by wind, because they are of low weight and display winged accessory fruits that help the spreading over seeds for long distances. The dispersal of seeds by the wind tends to increase among-population variability, although this depends on the velocity of the wind and on the characteristics of the seeds (Loveless \& Hamrick, 1984). Short migrations of seeds for long distances may constraint populational divergence.

Zeyheria montana is an allogamic species and presents self-incompatibility with genetic control (Bittencourt Jr. \& Semir, 2004). This feature contributes to a higher among-population variability. Since there is no self-pollination, the gene flow within population is enhanced and this explains the significant variability (15.97\%) among Z. montana populations. Though the variability among Z. montana populations was considered moderately high, it was twice superior if compared to the variability reported for Tabebuia impetinosa (Ciampi et al., 2003). Considering that the pollination of $Z$. montana is performed by hummingbirds Colibri serrirostris, Eupetomena macroura, Amazilia fimbriata and Melanotrochilus fuscus (Bittencourt Jr. \& Semir, 2004) and that these birds can fly over long distances, the variability found among populations may be related to this fact.

According to Solé-Cava (2001), populations of endangered species are in general structured, since environmental degradation usually leads to the formation of refuges (fragments), where small populations of the threatened species endure, with no possibility to exchange genes with other individuals located inside un- disturbed areas. Indeed, populations of Zeyheria montana form refuges that present high structuration. Thus, the present work brings together significant data to develop strategies for the conservation of the Cerrado endemic species Z. montana within the state of São Paulo.

The in situ conservation, or the preservation of the genetic variability in natural habitats, seems to be an effective alternative since local adaptations benefit the establishment of this species in areas of natural occurrence, as for individuals collected from remaining preserved Cerrado areas in Mogi Guaçu and Pedregulho (Populations $\mathbf{F}$ and $\mathbf{H}$ ). Most Z. montana individuals were found in private areas with different levels of anthropization and not protected by conservation policies, therefore these accessions should be introduced in germplasm banks.

As a conclusion, the genetic variability of Zeyheria montana natural populations found in the state of São Paulo, analyzed via RAPD molecular markers, has a significant interpopulational component, but no spatial pattern. It seems that the obtained results support a model of partially isolated islands, advancing independently into the genetic space. No isolation-by-distance pattern was defined at this spatial scale, wherein neighbor populations or in close proximity would share more genetic similarity. This has important consequences for population conservation and management.

\section{ACKNOWLEDGEMENTS}

To UNAERP and FAPESP (Biota-FAPESP, Process 99-10610/1) for financial support.

\section{REFERENCES}

ALMEIDA, E.R.; SILVA FILHO, A.A.; SANTOS, E.R.; LOPES, C.A. Antiinflamatory action of lapachol. Journal of Ethnopharmacology, v.29, p.239-241, 1990.

ARNHOLDT-SCHMITT, B. RAPD analysis: a method to investigate aspects of the reproductive biology of Hypericum perforatum L. Theoretical Applied Genetics, v.100, p.906-911, 2000.

BITTENCOURT JR., N.S.; SEMIR, J. Pollination biology and breeding system of Zeyheria montana (Bignoniaceae). Plant Systematics and Evolution, v.247, p.241-254, 2004.

BRANDON, K.; FONSECA, G.A.B.; RYLANDS, A.B.; SILVA, J.M.C. Conservação brasileira: desafios e oportunidades. Megadiversidade, v.1, p.7-13, 2005.

CIAMPI, A.Y.; AZEVEDO, V.C.R.; SILVA, V.P. Análise genética populacional de Tabebuia impetiginosa utilizando marcadores moleculares RAPD. Brasília: Embrapa Recursos Genéticos e Biotecnologia, 2003. 18p. (Boletim de Pesquisa e Desenvolvimento).

CORRÊIA, M.P. Dicionário das plantas úteis do brasil e das exóticas cultivadas. Rio de Janeiro: Imprensa Nacional, Ministério da Agricultura; IBDF, 1931. 400p.

DAHER, R.F.; PEREIRA, M.G.; PEREIRA, A.V.; AMRARAL JR., A.T. Genetic divergence among elephantgrass cultivars assessed by RAPD markers in composit samples. Scientia Agricola, v.59, p.623-627, 2002. 
DOYLE, J.J.; DOYLE, J.L. Isolation of plant DNA from fresh tissue. Focus, v.12, p.13-15, 1987.

FELFILI, J.M.; SILVA JR., M.C.; SEVILHA, A.C.; FAGG, C.W.; WALTER, B.M.T.; NOGUEIRA, P.E.; REZENDE, A.V. Diversity, floristic and structural patters of cerrado vegetation in Central Brasil. Plant Ecology, v.175, p.37-46, 2004.

FERREIRA, M.E.; GRATTAPAGLIA, D. Introdução ao uso de marcadores moleculares em análise genética. Brasília: Embrapa Cenargen, 1998. 220p.

FERREIRA JR., O. GPS TrackMaker ${ }^{\circledR}$ for Windows® versão 11.7. Programa para computador Belo Horizonte, 2001. Available on: <www.gpstm.com.br>.

GAUER, L.; CAVALLI-MOLINA, S. Genetic variation in natural populations of maté (Ilex paraguariensis A. St.-Hil., Aquifoliaceae) using RAPD markers. Heredity, v.84, p.647656, 2000

GILLIES, A.C.M.; NAVARRO, C.; LOWE, A.J.; NEWTON, C.A.; HERNÁNDEZ, M.; WILSON, J.; CORNELIUS, J.P. Genetic diversity in Mesoamerican populations of mahogany (Swietenia macrophylla), assessed using RAPDs. Heredity, v.83, p.722732, 1999.

GIULIETTI, A.M.; HARLEY, R.M.; QUEIROZ, L.P.; WANDERLEY, M.G.; BERG, C.V.D. Biodiversidade e conservação das plantas no Brasil. Megadiversidade, v.1, p.5261, 2005.

GOEL, R.K.; PATHAK, N.K.; BISWAS, M.; PANDE, Y.V.B.; SANYAL, A.K. Effect of lapachol, a naphthaquinone isolated from Tectona grandis on experimental peptic ulcer and gastric secretion. Journal of Pharmacy and Pharmacology, v.39, p.138-140, 1987.

HAIG, S.M. Molecular contributions to conservation. Ecology, v.79, p.413-425, 1998.

JACOME, R.L.R.; OLIVEIRA, A.B.; RASLAN, D.S.; MULLER, A.; WAGNER, H. Análise de Naftoquinonas em extratos brutos de raízes de Zeyheria montana M. (bolsa de pastor). Química Nova, v.22, p.175-177, 1999.

KLINK, A.C.; MACHADO, R.B. A conservação do Cerrado brasileiro. Megabiodiversidade, v.1, p.147-155, 2005.

KROTH, M.A.; RAMELLA, M.S.; TAGLIARI, C.; FRANCISCO, A; ARISI, A.C.M. Genetic similarity of Brazilian Hull-Less and malting barley varieties evaluated by RAPD markers. Scientia Agricola, v.62, p.36-39, 2005.

LACERDA, D.R.; ACEDO, D,P.; LEMOS FILHO, J.P.; LOVATO, M.B. A técnica de RAPD: uma ferramenta molecular em estudos de conservação de plantas. Lundiana, v.3, n.2, p.87-92, 2002.

LOVELESS, M.D.; HAMRICK, J.L. Ecological determinants of genetic structure in plant populations. Annual Review of Ecology and Systematics, v.15, p.65-95, 1984.

MANLY, B.F.J. Randomization and regression methods for testing for associations with geographical, environmental and biological distances between populations. Researches on Population Ecology, v.28, p.201-218, 1986.

MILLER, M.P. TFPGA 1.03: Tools for populations genetic analyses. 1997. Available on: <http://www.marksgeneticsoftwear.net/ tfpga.htm>. Accessed on: 22/02/2005.

MYERS N.; MITTERMEIER, R.A.; MITTERMEIER, C.G.; FONSECA, G.B.A.; KENT, J. Biodiversity hotspots for conservation priorities. Nature, v.403, p.853-858, 2000.
PARKER, P.G.; SNOW, A.A.; SCHUG, M.D.; BOOTON, G.C.; FUREST, P.A. What molecules can tell us about populations: choosing and using a molecular marker. Ecology, v.79, p.361382, 1998.

RODRIGUES, F.M.; DINIZ-FILHO, J.A.F. Hierarchical structure of genetic distances: effects of matrix size, spatial distribution and correlation structure among gene frequencies. Genetics and Molecular Biology, v.21, p.233-240, 1998.

ROHLF, F.J. NTSYS-Pc: Numerical Taxonomy and Multivariate Analysis System. New York: Exeter Publishers, 1989.

RUSSELL, J.R.; HOSEIN F.; JOHNSON, E.; WAUGH, R.; POWELL, W. Genetic. differentiation of cocoa (Theobroma cacao L.) populations revealed by RAPD analysis. Molecular Ecology, v.2, p.89-97, 1993.

SANDHU, S.S.; ABREU, I.N.; COLOMBO, C.A.; MAZZAFERA, P. Pilocarpine content and molecular diversity in Jaborandi. Scientia Agricola, v.63, p.478-482, 2006.

SANTANA, C.F.; LINS, L.J.P.; ASFORA, J.J.; MELO, A.M.; LIMA, O.G.; D’ALBUQUERQUE, I.L; Preliminary observations with the use of lapachol in human patients bearing malignant neoplasm. Revista do Instituto de Antibióticos, v.20, p.6168, 1980.

SALES, E.; NEBAUER, S.G.; MUS, M.; SEGURA, J. Population genetic study in the Balearic endemic plant species Digitalis minor (Scrophulariaceae) using RAPD markers. American Journal of Botany, v.88, p.1750-1759, 2001.

SCHNEIDER, S.; ROESSLI, D.; EXCOFFIER, L. Arlequin. Ver. 2.000: A software for population genetic data analysis. Available on: http://anthro.unige.ch/arlequin. Accessed on: 12 Sep. 2006.

SOARES, T.N.; CHAVES, L.J.; TELLES, M.P.C.; DINIZ-FILHO, J.A.F.; RESENDE, L.V. Landscape conservation genetics of Dipteryx alata ("baru” tree: Fabaaceae) from Cerrado region of central Brasil. Genetica, 2007 (submitted).SOLÉ-CAVA, A.M. Biodiversidade molecular e genética da conservação. In: MATIOLI, S.R (Ed.). Biologia molecular e evolução. Ribeirão Preto: Holos, 2001. 203p.

SONG, G.E.; OLIVEIRA, G.C.X.; SCHAAL, B.A.; GAO, L.-Z.; HONG, D.-Y. RAPD variation within and between natural populations of wild rice Oryza rufipogon from China and Brazil. Heredity, v.82, p.638-644, 1999.

WADT, L.H.O.; KAGEYAMA, P.Y. Estrutura genética e sistema de acasalamento de Piper hispidinervum. Pesquisa Agropecuária Brasileira, v.39, p.151-157, 2004.

WELSH, J.; MCCLELLAND, M. Fingerprinting genomes using PCR with arbitrary primers. Nucleic Acids Research, v.18, p.7213-7218, 1990.

WILLIAMS, J.G.W.; KUBELIK, A.R.; LIVAK, K.J.; RAFALSKI, J.A.; TINGEY, S.V. DNA polymorphisms amplified by arbitrary primers are useful as genetic markers. Nucleic Acids Research, v.18, p.6531-6535, 1990.

WRIGT, S. Evolution and the genetics of population. Variability within and among natural populations. University of Chicago Press, Chicago. v.4, 1978. 580p.

Received October 17, 2006

Accepted May 03, 2007 